\title{
SARS-CoV-2 Omicron Neutralization After Heterologous Vaccine Boosting
}

Running Title- SARS-CoV-2 Booster Response to Omicron

Kirsten E. Lyke, M.D. ${ }^{1 *}$, Robert L. Atmar, M.D. ${ }^{2 *}$, Clara Dominguez Islas, Ph.D. ${ }^{3}$, Christine M. Posavad, Ph.D. ${ }^{3,4}$, Daniel Szydlo ${ }^{5}$, M.S., Rahul PaulChourdhury ${ }^{5}$, Meagan E. Deming, M.D., Ph.D. ${ }^{1}$, Amanda Eaton $^{6}$, Lisa A. Jackson, M.D., M.P.H. ${ }^{7}$, Angela R. Branche, M.D. ${ }^{8}$, Hana M. El Sahly, M.D. ${ }^{2}$, Christina A. Rostad, M.D. ${ }^{9}$, Judith M. Martin, M.D. ${ }^{10}$, Christine Johnston, M.D, M.P.H. ${ }^{3,4,11}$, Richard E. Rupp, M.D. ${ }^{12}$, Mark J. Mulligan, MD ${ }^{13}$, Rebecca C. Brady, M.D. ${ }^{14}$, Robert W. Frenck, Jr., M.D. ${ }^{14}$, Martín Bäcker, $\mathrm{MD}^{15}$, Angelica C. Kottkamp, MD ${ }^{13}$, Tara M. Babu, MD, MSc ${ }^{11}$, Kumaravel Rajakumar, M.D. ${ }^{10}$, Srilatha Edupuganti, M.D. ${ }^{16,17}$, David Dobrzynski, M.D. ${ }^{8}$, Rhea N. Coler, M.Sc., Ph.D. ${ }^{18,19}$, Janet I. Archer, M.Sc. ${ }^{20}$, Sonja Crandon, B.S.N. ${ }^{21}$, Jillian A. Zemanek, M.P.H. ${ }^{5}$, Elizabeth R. Brown, Sc.D. ${ }^{3}$, Kathleen M. Neuzil, M.D. ${ }^{1}$, David S. Stephens, M.D. ${ }^{16}$, Diane J. Post, Ph.D. ${ }^{21}$, Seema U. Nayak, M.D. ${ }^{21}$, Paul C. Roberts, Ph.D. ${ }^{21}$, John H. Beigel, M.D. ${ }^{21}$, David Montefiori, Ph.D. ${ }^{622}$, and the DMID 21-0012 Study Group**

* First and Senior authors contributed equally to the work

** The Mix and Match Team members are listed in the Supplemental Appendices

ClinicalTrials.gov \# NCT04889209

\section{Corresponding Authors:}

Kirsten E. Lyke, M.D.

Center for Vaccine Development and Global Health

685 W. Baltimore Street

Baltimore, MD 21201

Phone: +1 410-706-0462/5328

and

Robert L. Atmar, M.D.

1 Baylor Plaza, MSBCM280

Houston, TX 77030 
Phone: +1 713-798-6849

Email: ratmar@bcm.edu

Author's Affiliations:

${ }^{1}$ Center for Vaccine Development and Global Health, University of Maryland School of Medicine, Baltimore, MD; ${ }^{2}$ Departments of Medicine and Molecular Virology \& Microbiology, Baylor College of Medicine, Houston, TX; ${ }^{3}$ Vaccine and Infectious Disease Division, ${ }^{4}$ Departments of Laboratory Medicine \& Pathology, and ${ }^{5}$ Statistical Center for HIV/AIDS Research and Prevention (SCHARP), University of Washington, Fred Hutchinson Cancer Research Center, Seattle, WA; ${ }^{6}$ Duke Human Vaccine Institute, Duke University Medical Center, Durham, NC; ${ }^{7}$ Kaiser Permanente Washington Health Research Institute, Seattle, WA; ${ }^{8}$ Department of Medicine, Division of Infectious Diseases, University of Rochester, Rochester, NY; ${ }^{9}$ Department of Pediatrics and Center for Childhood Infections and Vaccines, Emory University School of Medicine and Children's Healthcare of Atlanta, Atlanta, GA; ${ }^{10}$ Department of Pediatrics, University of Pittsburgh School of Medicine, Pittsburgh, PA;

${ }^{11}$ Department of Medicine, University of Washington, Seattle, WA; ${ }^{12}$ Sealy Institute for Vaccine Sciences, University of Texas Medical Branch, Galveston, TX; ${ }^{13}$ NYU Langone Vaccine Center and Division of Infectious Diseases and Immunology, Department of Medicine, NYU Grossman School of Medicine, New York, NY; ${ }^{14}$ Cincinnati Children's Hospital Medical Center, Division of Infectious Diseases, University of Cincinnati College of Medicine, Cincinnati, $\mathrm{OH} ;{ }^{15} \mathrm{NYU}$ Langone Hospital-Long Island Vaccine Center Research Clinic and Division of Infectious Disease, Department of Medicine, NYU Long Island School of Medicine, Mineola, NY; ${ }^{16}$ Department of Medicine, Emory University School of Medicine and ${ }^{17}$ Hope Clinic of Emory Vaccine Center, Atlanta, GA; ${ }^{18}$ Seattle Children's Research Institute and ${ }^{19}$ Department of Pediatrics, University of Washington School of Medicine, 
medRxiv preprint doi: https://doi.org/10.1101/2022.01.13.22268861; this version posted January 14, 2022. The copyright holder for this preprint

(which was not certified by peer review) is the author/funder, who has granted medRxiv a license to display the preprint in perpetuity.

All rights reserved. No reuse allowed without permission.

Seattle WA; ${ }^{20} \mathrm{FHI} 360$, Durham, NC 27701; ${ }^{21}$ Division of Microbiology and Infectious Diseases,

National Institute of Allergy and Infectious Diseases, National Institutes of Health, Bethesda, MD;

${ }^{22}$ Department of Surgery, Duke University Medical Center, Durham, NC

(Funded by National Institute of Allergy and Infectious Diseases; Clinical Trials.gov number,

NCT04889209)

Key Words (3-10): Covid-19, SARS-CoV-2, Booster, Vaccine, Omicron, Neutralizing antibody, mRNA, recombinant adenovirus 
medRxiv preprint doi: https://doi.org/10.1101/2022.01.13.22268861; this version posted January 14, 2022. The copyright holder for this preprint (which was not certified by peer review) is the author/funder, who has granted medRxiv a license to display the preprint in perpetuity.

All rights reserved. No reuse allowed without permission.

Abstract:

As part of an ongoing study assessing homologous and heterologous booster vaccines, following primary EUA series, we assessed neutralization of D614G and Omicron variants prior to and 28 days after boost.

Subset analysis was done in six combinations ( $N=10$ /group): four homologous primary-booster combinations included mRNA-1273 two-dose priming followed by boosting with $100-\mu \mathrm{g}$ or $50-\mu \mathrm{g}$ mRNA1273, Ad26.COV2.S single-dose priming followed by Ad26.COV2.S booster and BNT162 b2 two-dose priming followed by BNT162b2 boosting; and two heterologous primary-booster combinations: BNT162b2 followed by Ad26.COV2.S and Ad26.COV2.S followed by BNT162b2. Neutralizing antibody (Nab) titers to D614G on the day of boost (baseline) were detected in $85-100 \%$ of participants, with geometric mean titers (GMT) of 71-343 in participants who received an mRNA vaccine series versus GMTs of 35-41 in participants primed with Ad26.OV2.S. Baseline NAb titers to Omicron were detected in $50-90 \%$ of participants who received an mRNA vaccine series (GMT range $12.8-24.5$ ) versus $20-25 \%$ among participants primed with Ad26.COV2.S. The booster dose increased the neutralizing GMT in most combinations to above 1000 for D614G and above 250 for Omicron by Day 29. Homologous prime-boost Ad26.COV2.S had the lowest NAb on Day 29 (D614G GMT 128 and Omicron GMT 45). Results were similar between age groups. Most homologous and heterologous boost combinations examined will increase humoral immunity to the Omicron variant. 
medRxiv preprint doi: https://doi.org/10.1101/2022.01.13.22268861; this version posted January 14, 2022. The copyright holder for this preprint (which was not certified by peer review) is the author/funder, who has granted medRxiv a license to display the preprint in perpetuity.

All rights reserved. No reuse allowed without permission.

The Severe Acute Respiratory Syndrome Coronavirus 2 (SARS-CoV-2) Omicron (B.1.1.529) variant of concern, first reported to the World Health Organization on November 24, 2021, has become the dominant circulating strain in the United States.${ }^{1}$ The large number of mutations, including 15 within the spike protein's receptor binding domain, are associated with increased transmissibility, escape from therapeutic antibodies, and partial resistance to natural- and vaccine-induced immunity, with increasing breakthrough infections. ${ }^{2.3}$ As part of an ongoing study assessing homologous and heterologous booster vaccines, ${ }^{4}$ we assessed neutralization of $\mathrm{D} 614 \mathrm{G}$ and Omicron variants.

Six combinations were assessed: four homologous primary-booster combinations included mRNA-1273 (Moderna, two doses of $100-\mu \mathrm{g}$ ) followed by boosting with $100-\mu \mathrm{g}$ or $50-\mu \mathrm{g}$ mRNA-1273, Ad26.COV2.S (Janssen, one dose of $5 \times 10^{10}$ virus particles) followed by the same dose of Ad25.COV2.S and BNT162b2 (Pfizer-BioNTech, two doses of 30- $\mu \mathrm{g}$ ) followed by 30- $\mu \mathrm{g}$ of BNT162b2; and two heterologous primary-booster combinations: BNT162b2 followed by Ad26.COV2.S and Ad26.COV2.S followed by BNT162b2, with booster intervals ranging from 3-6.5 months. Samples from a randomly selected subset of 20 participants per group (10 participants $18-55$ years old and 10 participants $\geq 56$ years) were assayed. We determined $50 \%$ serum neutralizing antibody (NAb) titers using a lentivirusbased pseudovirus assay ${ }^{5}$ against the D614G reference standard (reported previously ${ }^{4}$ for all groups but the 50- $\mu \mathrm{g}$ mRNA-1273 homologous boost group) and Omicron spike variants from Day 1 (pre-boost) and Day 29 post-boost. $^{4}$

NAb titers to D614G on the day of boost (Day 1, baseline) were detected in $85-100 \%$ of participants, with geometric mean titers (GMT) of 71-343 in participants who received an EUA mRNA vaccine series versus GMT 35-41 in participants primed with Ad26.OV2.S (supplemental material). Baseline NAb titers to Omicron were detected in $50-90 \%$ of participants who received an EUA mRNA vaccine series (GMT range 12.8-24.5) versus 20-25\% among participants primed with Ad26.COV2.S (GMT range 7.2-7.6). Titers were 6.0-14.0-fold lower relative to D614G. The booster dose increased the neutralizing GMT in 
medRxiv preprint doi: https://doi.org/10.1101/2022.01.13.22268861; this version posted January 14, 2022. The copyright holder for this preprint (which was not certified by peer review) is the author/funder, who has granted medRxiv a license to display the preprint in perpetuity.

All rights reserved. No reuse allowed without permission.

most combinations to above 1000 for D614G and above 250 for Omicron (Figure). Homologous primeboost Ad26.COV2.S had the lowest NAb on Day 29 (D614G GMT 128 and Omicron GMT 45). After boost, the GMTs were 2.3-7.5-fold lower for Omicron as compared to D614G. Results were similar between age groups.

Homologous or heterologous boosts with available EUA vaccines provide post-boost titers to Omicron that have been associated with $>85 \%$ protection against symptomatic SARS-CoV-2 infection with D614G and B.1.1.7 (Alpha), in most combinations tested. ${ }^{5}$ Homologous prime-boost Ad26.COV2-S is the exception, with post-boost NAb being lower than other combinations. All combinations tested decreased the difference in titers between D614G and Omicron after boost. The 50-ug Moderna booster achieved similar NAb titers against Omicron as the 100 -ug dose, including in those $\geq 56$ years. Although vaccine-induced nNAb correlate with protection against illness, real world effectiveness data and better understanding of the role of cell-mediated immunity and correlates of protection against severe disease are needed. Additionally, the kinetics of the NAb post-boost are unknown - a factor critical to understanding the need for additional boosters Taken together, these data support that most homologous and heterologous boost combinations will increase humoral immunity to Omicron and can be considered as a strategy to mitigate risk from this variant.

\section{Figure 1}

Pseudovirus neutralization expressed as 50\% inhibitory dilution (ID50) to D614G and Omicron at Day 1 (pre-booster) and Day 29 for the combinations: A) mRNA-1273 EUA vaccine boosted with mRNA-1273 100- $\mu$ g; B) Ad26.COV2.S EUA vaccine boosted with Ad26.COV2.S; C) BNT162b2 EUA vaccine boosted with BNT162b2; D) mRNA-1273 EUA vaccine boosted with mRNA-1273 50- $\mu$ g; E) Ad26.COV2.S EUA vaccine boosted with BNT162b2; and F) BNT162b2 EUA vaccine boosted with Ad26.COV2.S. G) post- 
medRxiv preprint doi: https://doi.org/10.1101/2022.01.13.22268861; this version posted January 14, 2022. The copyright holder for this preprint (which was not certified by peer review) is the author/funder, who has granted medRxiv a license to display the preprint in perpetuity.

All rights reserved. No reuse allowed without permission.

boost pseudovirus neutralization to Omicron for all combinations. Box plots represent median

(horizontal line within the box) and 25th and 75th percentiles (lower and upper borders of the box), with the whiskers drawn to the value nearest to, but within, $1.5 \times$ IQR above and below the borders of the box.

\section{Funding and Acknowledgements:}

The trial was sponsored and primarily funded by the Infectious Diseases Clinical Research Consortium through the National Institute for Allergy and Infectious Diseases (NIAID) of the National Institutes of Health (NIH), under award numbers UM1AI48372, UM1Al148373, UM1AI148450, UM1Al148452, UM1Al148573, UM1Al148574, UM1AI148575, UM1Al148576, UM1Al148684, UM1 Al148689 and with support from the NIAID Collaborative Influenza Vaccine Innovation Centers (CIVICs) contract 75N93019C00050 and NIH Vaccine Research Center.

We would like to acknowledge Moderna, Inc., Johnson \& Johnson/Janssen, and Pfizer/BioNTech Pharmaceuticals for their collaboration, scientific input, and sharing of documents needed to implement this trial. All products were acquired through the government procurement process.

\section{References}

1. World Health Organization. Classification of Omicron (B.1.1.529): SARS-CoV-2 variant of concern. Geneva, Switzerland: World Health Organization; 2021. Accessed December 22, 2021. https://www.who.int/news/item/26-11-2021-classification-of-omicron-(b.1.1.529)-sars-cov-2-variantof-concern

2. CDC. Science brief: Omicron (B.1.1.529) variant. Atlanta, GA: US Department of Health and Human Services, CDC; updated 12/2/2021. Accessed December 22, 2021. https://www.cdc.gov/coronavirus/2019-ncov/science/science-briefs/scientific-brief-omicronvariant.html 
medRxiv preprint doi: https://doi.org/10.1101/2022.01.13.22268861; this version posted January 14, 2022. The copyright holder for this preprint (which was not certified by peer review) is the author/funder, who has granted medRxiv a license to display the preprint in perpetuity.

All rights reserved. No reuse allowed without permission.

3. CDC. Potential rapid increase of omicron variant infection in the United States. Updated 12/20/2021. Accessed 12/22/2021. https://www.cdc.gov/coronavirus/2019-ncov/science/forecasting/mathematicalmodeling-outbreak.html

4. Atmar RL, Lyke KE, Deming ME, Jackson LA, Branche AR, El Sahly HM, Rostad CA, Martin JM, Johnston C, Rupp RE, Mulligan MJ, Brady RC, Frenck RW Jr, Bäcker M, Kottkamp AC, Babu TM, Rajakumar K, Edupuganti S, Dobrzynski D, Coler RN, Posavad CM, Archer JI, Crandon S, Nayak SU, Szydlo D, Zemanek JA, Dominguez Islas CP, Brown ER, Suthar MS, McElrath MJ, McDermott AB, O'Connell SE, Montefiori DC, Earon A, Neuzil KM, Stephens DS, Roberts PC, Beigel JH, DMID 21-0012 Study Group. Heterologous SARS-CoV-2 Booster Vaccinations - Preliminary Report. medRxiv 2021.10.10.21264827; doi: https://doi.org/10.1101/2021.10.10.21264827

5. Gilbert PB, Montefiori DC, McDermott AB, Fong Y, Benkeser D, Deng W, Zhou H, Houchens CR, Martins K, Jayashankar L, Castellino F, Flach B, Lin BC, O'Connell S, McDanal C, Eaton A, Sarzotti-Kelsoe M, Lu Y, Yu C, Borate B, van der Laan LWP, Hejazi NS, Huynh C, Miller J, El Sahly HM, Baden LR, Baron M, De La Cruz L, Gay C, Kalams S, Kelley CF, Andrasik MP, Kublin JG, Corey L, Neuzil KM, Carpp LN, Pajon R, Follmann D, Donis RO, Koup RA; Immune Assays Team§; Moderna, Inc. Team; Coronavirus Vaccine Prevention Network (CoVPN)/Coronavirus Efficacy (COVE) Team; United States Government (USG)/CoVPN Biostatistics Team. Immune correlates analysis of the mRNA-1273 COVID-19 vaccine efficacy clinical trial. Science. 2021 Nov 23:eab3435. Epub ahead of print. PMID: 34812653. 
